http://dx.doi.org/10.12775/szhf.2013.054

\title{
Etyka filozoficzna jako hermeneutyka moralności
}

Nie będziemy mówić tutaj o możliwości ufundowania etyki filozoficznej na teoretycznej podstawie, jaką może stanowić dla niej hermeneutyka. Przedmiotem mojego zainteresowania w niniejszym artykule nie będzie zatem etyka hermeneutyczna, lecz jedynie możliwość odniesienia hermeneutyki do specyfiki i problemów filozoficznej etyki ${ }^{1}$. Chodzi zatem o hermeneutykę rozumianą jako drugi, obok normatywnej refleksji krytycznej, charakterystyczny wymiar etyki filozoficznej².

Czy hermeneutyka filozoficzna może być dla etyki propozycją metodologiczną, a jeśli tak, to w jakim sensie? Po jednoznacznie krytycznych wypowiedziach Gadamera na temat metody wydaje się, że myśl, iż hermeneutyka może stanowić remedium na metodologiczne problemy etyki filozoficznej jest merytorycznie niestosowna. Taka supozycja okazałaby się jednak całkowicie fałszywa. Wgląd w tę kwestię pozwala stwierdzić, że podejrzliwość Gadamera względem metody jest wynikiem jego sprzeciwu wobec absolutyzacji metodycznego poznania nauk przyrodniczych i nowożytnego zawężenia ob-

${ }^{1}$ Por. G. Figal, Ethik und Hermeneutik, [w:] H.-M. Schönherr-Mann, Ethik als Hermeneutik, Wilhelm Fink Verlag, München 2004, s. 117-118.

${ }^{2}$ Por. T. Siwiec, Etyka filozoficzna jako normatywna refleksja krytyczna, „Kultura i Wartości” 2012, nr 1, s. 32-48, www.kulturaiwartosci.umcs.lublin.pl/wp-content/uploads/2011/11/ Tomasz-Siwiec-Etyka-filozoficzna-jako-normatywna-refleksja-krytyczna2.pdf (dostęp: 9 października 2013 r.). 
szaru możliwej sedymentacji sensu wyłącznie do poznania metodycznego, właściwego dla przyrodoznawstwa ${ }^{3}$. Gadamer zauważa, że do specyfiki wiedzy uzyskanej na drodze takiego poznania należy to, iż:

we wszystkich obszarach dokonuje abstrakcji, które izolują pojedyncze związki przyczynowe. Musi ona zatem pogodzić się z nieuniknioną partykularnością jej [to jest abstrakcji - T. S.] kompetencji ${ }^{4}$.

Twierdzenie Gadamera w dużej mierze opiera się na przekonaniu, że nowożytna idea nauki zmieniła dotychczasową relację teorii i praktyki. Począwszy od połowy XVII wieku nauka nie była już ogółem wiedzy o świecie i człowieku. Kartezjańska Rozprawa o metodzie podstawą wiedzy czyni tylko to, co jasne i wyraźne, miarą zaś adekwatności wszelkiego poznania staje się idea pewności ${ }^{5}$ W swojej najobszerniejszej pracy poświęconej metodzie Kartezjusz pisze:

Przez metodę zaś rozumiem pewne i łatwe prawidła, których jeśli kto będzie ściśle przestrzegał, ten nigdy nie przyjmie czegoś fałszywego za prawdę i nie tracąc na darmo żadnego wysiłku umysłowego, będzie zawsze stopniowo powiększał swą wiedzę i dojdzie do prawdziwego poznania wszystkiego, co poznać jest zdolny. [...] Cała metoda polega na porządkowaniu i rozłożeniu tego, na co należy zwrócić spojrzenie umysłu, aby odkryć jakąś prawdę. Otóż metody tej będziemy ściśle przestrzegać, jeśli zdania zawiłe i ciemne sprowadzimy stopniowo do prostych, a następnie spróbujemy od intuicji tych, które są najprostsze ze wszystkich, wznieść się do poznania wszystkich innych ${ }^{6}$.

Kartezjuszowi nie chodzi zatem o wiedzę zdobywaną na drodze doświadczeń życiowych i poświadczoną sytuacjami, wynikającymi z szeregu działań

${ }^{3}$ Por. M. Szulakiewicz, Filozofia jako hermeneutyka, Wyd. UMK, Toruń 2008, s. 31-32; G. Vattimo, Społeczeństwo przejrzyste, tłum. M. Kamińska, Wyd. Naukowe Dolnośląskiej Szkoły Wyższej Edukacji TWP, Wrocław 2006, s. 111.

${ }^{4}$ H.-G. Gadamer, Teoria, technika, praktyka, tłum. A. Przyłębski, [w:] tegoż, Teoria, etyka, edukacja. Eseje wybrane, wybór R. Godoń, wstęp i opracowanie P. Dybel, Wyd. UW, Warszawa 2008, s. 44. Analogiczną w duchu krytykę poznania, które dokonuje się na drodze abstrahowania, przeprowadził Ernst Cassirer. Por. E. Cassirer, Substancja i funkcja. Badania nad podstawowymi problemami krytyki poznania, tłum. P. Parszutowicz, Wyd. Marek Derewiecki, Kęty 2008, s. 28-31.

${ }^{5}$ Por. H.-G. Gadamer, Teoria, technika, praktyka, s. 43.

${ }^{6}$ R. Descartes, Reguły kierowania umysłem, [w:] tegoż, Reguły kierowania umysłem. Poszukiwanie prawdy poprzez światło naturalne, tłum. L. Chmaj, Wyd. Antyk, Kęty 2002, s. 23 i 28. 
realizowanych przez podmiot. Wiedza uzyskana na drodze poznania naukowego posiada specyficzny rys aplikowalności, w którym chodzi o możność sprawczą, rozumianą przede wszystkim jako umiejętność panowania nad przyrodą.

Wraz z rozwojem naukowego przyrodoznawstwa i przyporządkowanej mu funkcjonalnej racjonalności, nakierowanej na przyczynowe wyjaśnianie badanych zjawisk, pojęcie natury uległo siłą rzeczy stopniowej dewaluacji. Jak trafnie zauważa Zbigniew Łepko, rok 1620 (data opublikowania Novum Organum) ma charakter symboliczny, ponieważ jest początkiem propagowanej przez Francisa Bacona nowej, w stosunku do starożytnej i średniowiecznej, strategii naukowego badania przyrody. Podczas gdy w starożytności i średniowieczu poznanie przyrody stanowiło cel sam w sobie i było elementem samorozumienia człowieka w całości świata, w czasach nowożytnych zaczęto je traktować jako środek prowadzący do wzrostu powszechnego dobrobytu ludzkości ${ }^{7}$. „Nie zakładamy - mówi Bacon w przedmowie do swojej Instauratio magna - fundamentów jakiejśs szkoły czy doktryny; lecz fundamentu ludzkiego dobra i wielkości”" Zgodnie z projektem Bacona miało to być poznanie sprzężone $\mathrm{z}$ techniką, dostarczające człowiekowi środków do panowania nad przyrodą i efektywnego uwalniania się od biedy materialnej. Racjonalność przyczynowa była zatem narzędziem dającym władzę i pozwalającym modyfikować stosunki społeczne. „Wiedza i potęga ludzka - oświadcza Bacon w I księdze Novum Organum - to jedno i to samo, gdyż nieznajomość przyczyn pozbawia nas skutku"

Będąca konsekwencją duchowego testamentu Bacona obiektywizacja natury doprowadziła do przedefiniowania stosunku człowieka do przyrody; przyroda jest odtąd tym, co zewnętrzne, co można uprzedmiotowić i zredukować do matematycznie określonych relacji ruchu i materii ${ }^{10}$. W konsekwencji Bacon jednoznacznie stwierdza bezużyteczność teleologii; kiedy przyroda staje się dziedziną technicznego przetwarzania, trzeba zawiesić pytanie o jej immanentne cele. $\mathrm{W}$ ten oto sposób przyroda stała się zwykłym przedmiotem użycia, a w najlepszym razie magazynem prefabrykatów, teleologiczna

${ }^{7}$ Por. Z. Łepko, Spór o testament F. Bacona, „Studia Philosophiae Christianae”, 1998, nr 2, s. $53-60$.

${ }^{8}$ F. Bacon, Przedmowa do „Wielkiej odnowy”, [w:] tegoż, Novum Organum, tłum. J. Wikarjak, oprac. K. Ajdukiewicz, PWN, Warszawa 1955, s. 23.

${ }^{9}$ Por. F. Bacon, Novum Organum, s. 57.

${ }^{10}$ Por. G. Böhme, Filozofia i estetyka przyrody, tłum. J. Merecki, Oficyna Naukowa, Warszawa 2002, s. 51-53. 
perspektywa zaś może jedynie zakłócić proces jej opanowywania lub nawet zniwelować chęć jej użycia ${ }^{11}$. Nie sposób jednak ze zmatematyzowanej koncepcji przyrody wywieść choćby powinności lub „tego, co słuszne z natury”12.

Gadamer nie wypowiada się zatem przeciw metodzie w ogóle, lecz tylko przeciw nastawieniu, które $\mathrm{w}$ metodzie nauk przyrodniczych widzi jedyną podstawę dla wszelkiego rozumienia ${ }^{13}$. Nie metoda więc, lecz zaledwie, by użyć określenia Georga Henrika von Wrighta, „metodologiczny monizm pozytywistycznego myślenia" jest tym, czemu Gadamer się sprzeciwia ${ }^{14}$. Pisze on zresztą wprost, że:

Metody nauk przyrodniczych nie obejmują wszystkiego, co warte jest poznania, nie obejmują nawet tego, co jest najbardziej interesujące, mianowicie ostatecznych celów, którym służy wszelkie opanowanie środków natury i ludzi. Poznanie, które ma miejsce w naukach humanistycznych i filozofii, i którego możemy od nich oczekiwać, jest innego rodzaju i ma inną rangę ${ }^{15}$.

Zmiana filozoficznego nastawienia czy, mówiąc ściślej, zwrócenie uwagi na te elementy doświadczenia, w których objawia się sens niemożliwy do skonstatowania za pomocą nowożytnie rozumianej metody, świadczy pośrednio o ponownym zainteresowaniu filozofii sferą ludzkiej praxis, obejmującą te przedsięwzięcia, które poszukują możliwości zrozumienia poza dziedziną ograniczoną metodologicznym ideałem wiedzy ścisłej. Gadamerowska hermeneutyka, która niewątpliwie jest rzeczniczką takiego nastawienia, kierując się pytaniem o obszar sedymentacji sensu poza zakresem jurysdykcji wiedzy ścisłej, usiłuje go wskazać przede wszystkim na podstawie odniesienia do doświadczenia hermeneutycznego. Innymi słowy, hermeneutyka usiłuje wydobyć to, co w danym wypadku sens może oznaczać w kontekście urzeczywistniania możliwości bytu ludzkiego. Urzeczywistnienie to jest możliwe jedynie wówczas, gdy uzyskane wyniki poznania zostaną przez podmiot włączone w zakres jego osobistej wiedzy. Tylko wówczas, powiada Gadamer, będzie-

${ }^{11}$ Por. R. Spaemann, R. Löw, Cele naturalne. Dzieje i ponowne odkrycie myślenia teleologicznego, tłum. A. Połtawski, Oficyna Naukowa, Warszawa 2008, s. 109.

${ }^{12}$ Por. R. Spaemann, Die Aktualität des Naturrechts, [w:] tegoż, Philosophische Essays, Philipp Reclam, Stuttgart 1994, s. 67-69.

${ }^{13}$ Por. Z. Krasnodębski, Rozumienie ludzkiego zachowania. Rozważania o filozoficznych podstawach nauk humanistycznych i społecznych, PIW, Warszawa 1986, s. 183.

${ }^{14}$ Por. G. H. von Wright, Explanation and Understanding, Routledge \& Kegan Paul, London 1971, s. 4.

${ }^{15}$ H.-G. Gadamer, Prawda w naukach humanistycznych, tłum. A. Mergler, s. 102-103. 
my mogli mówić o „doświadczeniu” w ścisłym sensie tego słowa. W takim sposobie ujęcia problemu, teoria nie jest już jakimś szczególnie uprzywilejowanym nośnikiem sensu. Hermeneutyka wychodzi raczej z założenia, że w dziedzinie ludzkiej praktyki możliwe jest całkiem swoiste doświadczenie sensu, a to znaczy, że praktyka odkrywa prawdę, której nie da się uzyskać $\mathrm{z}$ teorii jako takiej. Treść tej prawdy nie może być jednak ponownie wyłożona w jej logiczno-formalnej strukturze. Chodzi raczej o to, by „treści zapośredniczone językowo doprowadzić do przyswojenia wraz z całym ich doświadczeniem historycznym" ${ }^{\prime \prime}$.

Gdybyśmy zatem chcieli mówić o hermeneutyce jako pewnej „propozycji metodologicznej" dla etyki, to niewątpliwie należałoby odejść od redukcjonistycznego pojęcia metody, które ogranicza się do zbioru technikaliów czy przepisów, określających efektywny sposób badania naukowego. Nastawienie badawcze, które od hermeneutyki oczekiwałoby poznawczego „wyczerpania” swojego przedmiotu, zamknięcia go w ostatecznej i niezmiennej formule, jest z góry skazane na porażkę. Hermeneutyka bowiem podkreśla właśnie historyczność i skończoność każdego rozumienia, jego zapośredniczenie przez fakt bycia w świecie. Oczywistą konsekwencją takiego podejścia do problemu rozumienia jest to, że jego przedmiot nigdy nie może zostać poznawczo wyczerpany, lecz pozostaje w ciągłym niedookreśleniu i otwartości. Wspomniane niedookreślenie wynika poniekąd również z faktu, że, jak pisze Paul Ricoeur:

Nie istnieje hermeneutyka ogólna, to znaczy ogólna teoria interpretacji, ogólny kanon egzegezy, istnieją tylko odrębne i przeciwstawne teorie hermeneutycz$n e^{17}$.

Czegóż więc etyka filozoficzna może oczekiwać od hermeneutyki? Niechęć do pozytywistycznej metodologii, akcentowanie historyczności rozumienia oraz odejście od epistemologii mumifikującej wyniki własnych badań nie wydają się dla etyki wystarczające, nawet jeśli hermeneutyka filozoficzna

\footnotetext{
${ }^{16}$ H.-G. Gadamer, O możliwościach etyki filozoficznej, tłum. A. Mergler, [w:] tegoż, Teoria, etyka, edukacja. Eseje wybrane, wybór R. Godoń, wstęp i opracowanie P. Dybel, Wyd. UW, Warszawa 2008, s. 130.

${ }^{17}$ P. Ricoeur, Hermeneutyka symboli a refleksja filozoficzna, tłum. J. Skoczylas, [w:] tegoż, Egzystencja i hermeneutyka. Rozprawy o metodzie, wybór S. Cichowicz, Warszawa 1985, s. 107.
} 
ma słuszność w odniesieniu do wymienionych wyżej kwestii ${ }^{18}$. Gdzie zatem upatrywać szansy aplikacji praktyki hermeneutycznej na grunt problematyki etycznej? Andrzej Przyłębski uważa, co skądinąd wydaje mi się słuszne, że w sposobie, w jaki Gadamer ujmuje sam problem rozumienia. Ma ono bowiem dla Gadamera zdecydowanie więcej wspólnego z Arystotelesowską phronesis niż z Kantowskim Verstand. To właśnie rozsądek (czy może lepiej mądrość praktyczna ${ }^{19}$ ), zasadzający się na zdobytym przez jednostkę doświadczeniu, a następnie wielokrotnie konfrontowany z napotykanymi w życiu problemami jest tym rodzajem wiedzy, który z punktu widzenia społecznej praxis jest najbardziej istotny ${ }^{20}$. Oddajmy głos Gadamerowi:

Musimy tedy zapytać ponownie: czym jest praktyka, co znaczy praktyka? A musimy się tu uczyć od Arystotelesa: jego pojęcie praktyki, które wypracowało odróżnienie między techne, wiedzą kierującą możnością sprawczą, a phronesis, wiedzą zawiadującą praktyką, nie ukształtowało się przeciwko theoria, lecz przeciwko duchowi wytwórczości. Odróżnienie to nie oznacza przecież oddzielenia, lecz uporządkowanie, a mianowicie podporządkowanie techne i jej możliwości oraz włączenie jej do phronesis i związanej z nią praxis ${ }^{21}$.

Odróżnienie techne od phronesis, jak zauważa Przyłębski, pozwala wydobyć ten zasadniczy element, który sprawia, że w odniesieniu do tej drugiej nie można mówić o jakiejkolwiek możliwości jej mistrzowskiego opanowania czy wyuczenia ${ }^{22}$. Phronesis to również coś znacznie więcej niż umiejętność rozstrzygnięcia czy określony czyn podpada pod ogólne prawidło czy też nie. W pojęciu phronesis nie chodzi zatem bynajmniej o to, aby do własnego postępowania in concreto stosować to, co w prawidle zostało wyrażone jedynie w sposób ogólny ${ }^{23}$. Z tego względu Gadamer uzna rozwiązanie Kanta w dziedzinie moralności za zbyt formalistyczne i tym samym dołączy do niemałego grona krytyków właśnie tego aspektu filozofii praktycznej królewieckiego

\footnotetext{
${ }^{18} \mathrm{Na}$ ograniczenia wykrojonej w ten sposób perspektywy zwraca również uwagę Günter Figal. Por. G. Figal, Ethik und Hermeneutik, s. 117.

${ }_{19}$ Por. K. Narecki, Słownik terminów Arystotelesowych, [w:] Arystoteles, Dzieła wszystkie, PWN, Warszawa 1994, t. 7, s. 124-125.

${ }^{20}$ Por. A. Przyłębski, Hermeneutyczny zwrot filozofii, Wyd. UAM, Poznań 2005, s. 262.

${ }^{21}$ H.-G. Gadamer, Obywatele dwóch światów, [w:] tegoż, Dziedzictwo Europy, tłum. i oprac.

A. Przyłębski, Wyd. Spacja, Warszawa 1992, s. 74-75.

${ }^{22}$ Por. A. Przyłębski, Hermeneutyczny zwrot filozofii, s. 256-266.

${ }^{23}$ Por. H.-G. Gadamer, Idea dobra $w$ dyskusji między Platonem a Arystotelesem, tłum. Z. Nerczuk, Wyd. Antyk, Kęty 2002, s. 121.
} 
filozofa ${ }^{24}$. W przekonaniu Gadamera istnieje nieusuwalne napięcie między „empiryczną zależnością ludzkiego rozumu i zakorzenionej w nim skłonności do zła" a możliwością sprawdzenia, czy dany czyn podpada pod prawo moralne ${ }^{25}$. Metodyczne powiązanie przez Kanta teoretycznego i praktycznego użycia rozumu w konsekwencji zdaje się przekreślać możliwość, by problemy ludzkiego sposobu życia przemówiły swoją własną rozumnością. Stąd uprawnione byłoby nazwanie Kantowskiej filozofii praktycznej „teorią praktyki”26. W konsekwencji Gadamer zbliża się do rozwiązania Arystotelesa, który większą wagę przykłada do społecznego uwarunkowania konkretnych decyzji moralnych niż do bezwarunkowości moralnych powinności ${ }^{27}$. Odróżniając teorię i praktykę, Arystoteles wychodzi od przekonania, że w kwestii sposobu życia nie może być żadnego czystego rozumienia tego, co jest, ponieważ w problemie wolności woli nie chodzi bynajmniej o teoretycznie uchwytną konieczność, ale o zasadę działania, tkwiącą w samym działającym podmiocie ${ }^{28}$.

W przekonaniu Gadamera Arystotelesowska analiza phronesis przypisuje wiedzę moralną do społecznego bytowania człowieka i czyni z niej element konkretnej sytuacji ${ }^{29}$. Etyka Arystotelesa próbuje zatem pośredniczyć mię-

${ }^{24}$ Por. H.-G. Gadamer, Wertethik und praktische Philosophie, [w:] tegoż, Gesammelte Werke, Bd. 4: Neuere Philosophie II. Probleme - Gestalten, Mohr Siebeck, Tubingen 1987, s. 213.

${ }^{25}$ Por. H.-G. Gadamer, O możliwościach etyki filozoficznej, tłum. A. Mergler, [w:] tegoż, Teoria, etyka, edukacja. Eseje wybrane, wybór R. Godoń, wstęp i opracowanie P. Dybel, Wyd. UW, Warszawa 2008, s. 130.

${ }^{26}$ Por. U. Hommes, Kanta krytyka praktycznego rozumu a wspótczesna filozofia praktyczna, tłum. A. Węgrzecki, „Studia Filozoficzne”, 1973, nr 4, s. 22-26.

${ }^{27} \mathrm{Na}$ temat recepcji filozofii praktycznej Arystotelesa w hermeneutyce Gadamera por. E. Berti, The Reception of Aristotle's Intellectual Virtues in Gadamer and the Hermeneutic Philosophy, [w:] The Impact of Aristotelianism on Modern Philosophy, R. Pozzo (ed.), The Catholic University of America Press, Washington 2003, s. 285-300.

${ }^{28}$ Zdzisław Krasnodębski zauważa, że „w zachowaniu praktycznym jako takim jest już zawarta «wiedza», do której nie sposób dojść w zachowaniu teoretycznym, polegającym na «wyłącznym przypatrywaniu się». Nie jest tak, iżby w jednym nastawieniu tylko się działało, a w drugim tylko poznawało rzeczy. Nie jest też tak, żeby działanie, aby nie być działaniem ślepym, musiało się odwoływać do poznania teoretycznego, oprzeć się na nim. Praktyczne zachowanie jest samo w sobie «poznawaniem». Dawne pojęcie praktyki oznaczało zresztą właśnie pewien swoisty typ wiedzy, a nie tylko stosowanie wiedzy". Por. Z. Krasnodębski, Rozumienie ludzkiego zachowania. Rozważania o filozoficznych podstawach nauk humanistycznych i społecznych, s. 186.

${ }^{29}$ Por. A. Wiercinski, Phronesis as the Mediation between Logos and Ethos, [w:] Hermeneutic Rationality. La rationalité herméneutique, red. M. L. Portocarrero, L. A. Umbelino, A. Wierciński, LIT Verlag, Münster 2012, ss. 73-86. 
dzy subiektywnością wiedzy moralnej a substancjalnością bytu ${ }^{30}$. Gadamer zauważa, że filozofia praktyczna może ułatwić podjęcie decyzji i wyostrzyć mądrość praktyczną tylko w takim stopniu, w jakim uwidacznia ona to, gdzie w ogóle można natrafić na problemy o charakterze moralnym i jak należy na nie patrzeć ${ }^{31}$. Sam Stagiryta w tym właśnie kontekście pisze:

Co się zaś tyczy rozsądku, możemy istotę jego ująć, rozważając, o jakich to ludziach mówimy, że są rozsądni. Zdaje się, że charakterystyczną ich cechą jest zdolność trafnego namysłu nad tym, co jest dla nich dobre i pożyteczne, i to nie w pewnych specjalnych dziedzinach, na przykład dla ich zdrowia czy siły, lecz w odniesieniu do należytego sposobu życia w ogóle ${ }^{32}$ (EN 1140 b 1-5).

Phronesis to zatem dla Arystotelesa nic innego jak zdolność trafnego namysłu, który ma określić sposób aplikacji nie tyle ogólnych pojęć sprawiedliwości czy odwagi, lecz to, co w konkretnej sytuacji jest dobre i pożyteczne. Gadamer słusznie zwraca uwagę, że przedmiotem phronesis nie jest żaden rodzaj powinności, ale to, co Arystoteles nazywa bliżej nieokreśloną formułą tego, co dobre i pożyteczne, co należy czynićs ${ }^{33}$. Jednoznaczną określoność mogą one uzyskać dopiero w konkretnej sytuacji, która wyznacza kierunek tego, co jest do zrobienia ${ }^{34}$. Dlatego, jakkolwiek Gadamer docenia wysiłki Kanta zmierzające do zachowania "transcendentalnej czystości” rozumu praktycznego, to jednak przyznaje rację Heglowi, który istotę moralności dostrzega raczej w obyczaju niż w imperatywnej etyce Kanta ${ }^{35}$. Dla Hegla moralność zawiera się zatem $\mathrm{w}$ „substancjalności porządku obyczajowego, który ma swoje ucieleśnienie $\mathrm{w}$ wielkich obiektywizacjach rodziny, społeczeństwa i państwa" ${ }^{36}$. Stąd też Gadamer postuluje konieczność zrelatywizowania rozumu względem etosu, widząc $\mathrm{w}$ tym ostatnim nie tyle podmiotową moralność konkretnej jednostki, ile wspólnotową formę życia, w której

\footnotetext{
${ }^{30}$ Por. H.-G. Gadamer, O możliwościach etyki filozoficznej, s. 136.

${ }^{31}$ Por. H.-G. Gadamer, Idea dobra w dyskusji między Platonem a Arystotelesem, s. 120.

${ }^{32}$ Arystoteles, Etyka nikomachejska, tłum. D. Gromska, [w:] tegoż, Dzieła wszystkie, PWN, Warszawa 1996, s. 197.

${ }^{33}$ Por. H.-G. Gadamer, Idea dobra w dyskusji między Platonem a Arystotelesem, s. 119.

${ }^{34}$ Por. H.-G. Gadamer, O możliwościach etyki filozoficznej, s. 136-137.

${ }^{35} \mathrm{Na}$ temat szczegółów Heglowskiej krytyki pojęcia imperatywu por. H. Schnädelbach, Hegel. Wprowadzenie, tłum. A. J. Noras, Oficyna Naukowa, Warszawa 2006, s. 136-138.

36 Tamże, s. 131-132. Na temat Heglowskiego pojęcia „etyczności” i jej form por. H. Schnädelbach, Hegel. Wprowadzenie, s. 139-140, a także E. Nowak-Juchacz, Autonomia jako zasada etyczności. Kant, Fichte, Hegel, Fundacja na Rzecz Nauki Polskiej, Wrocław 2002, s. 275-289.
} 
immanentnie obecna jest jego samoprezentacja. Podstawę dla niej stanowi wspólny „horyzont rozumienia”, jaki stwarza wspólnotowa forma życia. Dlatego słusznie podkreśla Przyłębski, że dla Gadamera ethos nie jest w żadnym razie irracjonalną podstawą moralności, ponieważ zawiera on swoją własną specyficzną rozumność ${ }^{37}$.

W rzeczywistości już Platon wykazał, że ethos stanowi podstawę, na bazie której możemy w ogóle rozwijać poczucie racjonalności w naszej ludzkiej egzystencji. [...] I właśnie o to nam tutaj chodzi - że dobro naszego działania nie może zostać określone $\mathrm{w}$ racjonalnym przedłożeniu, gdyż jego konkretności można doświadczyć jedynie w tej nierozerwalnej jedności ethosu i dianoii ${ }^{38}$.

W konsekwencji etyka filozoficzna, widziana w perspektywie hermeneutycznej, staje się w znacznie większym stopniu etyką dóbr (wzgl. etyką dążenia) niż etyką powinności ${ }^{39}$. W tej perspektywie treścią etyki filozoficznej, wyrażanej w naturalnym języku historycznie określonej społeczności, jest właśnie to, co Grecy określali mianem ethosu. Jest to właściwy dla danej kultury, społeczeństwa i epoki obyczaj, który z jednej strony bezlitośnie falsyfikuje „metodologiczny monizm pozytywistycznego myślenia” (by ponownie odwołać się do określenia von Wrighta), z drugiej natomiast demaskuje formalizm imperatywnej etyki Kanta ${ }^{40}$. Jest to zrozumiałe, jeśli hermeneutykę chcemy rozumieć jako odpowiedź na „historycznie ukierunkowane jawienie się bycia", gdyż wówczas jej głównym zadaniem powinno być zredefiniowanie stosunków, które współcześnie w najwyższym stopniu determinują ludzką egzystencję, to znaczy z nowoczesną nauką i techniką ${ }^{41}$. Gadamer jest przekonany, że:

${ }^{37}$ Por. A. Przyłębski, Hermeneutyczny zwrot filozofii, s. 269.

${ }^{38}$ H.-G. Gadamer, Vernunft und praktische Philosophie, [w:] tegoż, Gesammelte Werke, J. C. B. Mohr-Paul Siebeck, Tübingen 1995, t. 10, s. 263: „In Wahrheit hat Plato damit gezeigt, das Ethos die Basis ist, von der aus wir in unserer menschlichen Existenz überhaupt nur den Sinn für Rationalität entwickeln können. [...] Und eben das ist es, worum es dabei geht - dass das Gute unser Handeln nicht in einer rationalen Vorgegebenheit bestimmen kann, sondern nur in dieser unlösbaren Einheit von Ethos und Dianoia seine Konkretion erfährt".

${ }^{39}$ Por. G. Vattimo, Społeczeństwo przejrzyste, tłum. M. Kamińska, Wyd. Naukowe Dolnośląskiej Szkoły Wyższej Edukacji TWP, Wrocław 2006, s. 112.

${ }^{40}$ Por. H.-G. Gadamer, Ethos und Ethik, [w:] tegoż, Gesammelte Werke, Bd. 3: Neuere Philosophie I. Hegel, Husserl, Hiedegger, Mohr Siebeck, Tübingen 1987, s. 350-374.

${ }^{41}$ Por. G. Vattimo, Poza interpretacją. Znaczenie hermeneutyki dla filozofii, tłum. K. Kasia, Universitas, Kraków 2011, s. 43. 
Dopiero to nadaje filozofii praktycznej z powrotem jej dawną godność, która polega nie tylko na rozpoznaniu tego, co dobre, ale także na jego współrealizowaniu. Nie oznacza to bynajmniej, że za słuszne uważałbym merytoryczne zrehabilitowanie greckiej etyki, ale raczej by odświeżone zostały metodyczne idee filozofii praktycznej. Stałaby się ona na powrót „etyką," czyli ogólnym sprawozdaniem nie z treści jakiejś uświadomionej wartości, ale z całości społecznej rzeczywistości przeżywanej w prawie i w obyczaju, to znaczy w etosie ${ }^{42}$.

Oparcie etyki filozoficznej na pojęciu etosu, jest w moim przekonaniu momentem przełomowym, w którym hermeneutyka restytuuje zapomniany wymiar filozofii praktycznej, związany z jednej strony z postawą moralną podmiotu, $z$ drugiej zaś ze społecznymi formami życia i wynikającymi z nich regułami. Hermeneutyka jako sztuka interpretacji jawi się wówczas jako poręczne narzędzie, za pomocą którego etyka może zdać sprawę zarówno z treści konkretnych fenomenów moralnych, jak i z wielorakich form moralności i świadomości moralnej. Andrzej Przyłębski nie bez racji podkreśla, że hermeneutyka filozoficzna, świadoma roli wymiaru historycznego w interpretacji fenomenów moralnych, jest szczególnie predestynowana do interpretacji historycznych doświadczeń i zwrotów dziejowych, będących udziałem różnych epok, jako wydarzeń o charakterze moralnym ${ }^{43}$. Wizje „nowego człowieka" oraz fundamentalistyczno-autorytarne ruchy polityczne i społeczne byłyby wówczas interpretowane nie tylko w horyzoncie historycznej faktografii, ale przede wszystkim jako wydarzenia świadczące o kryzysie społecznej świadomości moralnej; kryzysie, który domaga się zrozumienia i wykładni. Przy czym zadanie to nie zostaje przez hermeneutykę podjęte w celu wyartykułowania przeszłości czy zdania prostego rachunku zysków i strat. Intencją przewodnią jest tu raczej udzielenie ostrzeżenia na przyszłość (ale

\footnotetext{
${ }^{42}$ H.-G. Gadamer, Wertethik und praktische Philosophie, s. 213-214: „Das erst gäbe der praktischen Philosophie ihre alte Würde zurück, das Gute nicht nur zu erkennen, sondern auch mitzubefördern. Das würde keineswegs bedeuten, daß die griechische Ethik eine inhaltliche Rehabilitierung fände - wohl aber, daß die methodiche Idee der praktischen Philosophie wiederhergestellt würde. Sie würde wieder „Ethik”, d.h. eine allgemeine Rechenschaftsgabe nicht über die Inhalte eines Wertbewußtseins, sondern über das Ganze der in Recht und Sitte, d.h. im Ethos gelebten gesellschaftlichen Wirklichkeit".

${ }^{43}$ Por. A. Przyłębski, Etyka w świetle hermeneutyki, Warszawa: Oficyna Naukowa 2010, s. 163, 168.
} 
także konfrontacja z teraźniejszością), które pod pozorem omawiania przeszłości zostaje jedynie ukryte ${ }^{44}$. Słusznie zauważył Walter Benjamin, że

Wyartykułować historycznie to, co minione, nie oznacza, że trzeba je poznać „takim, jakie naprawdę było”. Oznacza natomiast zawładnąć przypomnieniem, takim, jakie rozbłyska w chwili zagrożenia ${ }^{45}$.

$Z$ drugiej strony nie ma również najmniejszej wątpliwości co do tego, że etyka filozoficzna posiada swój własny, specyficzny system kategorii oraz siatkę pojęciową. Od stopnia jej rozbudowania zależy bezpośrednio sama struktura etyki. Oczywiste jest również przy tym, że etyka filozoficzna, będąc rodzajem refleksji teoretycznej, dzięki swoim kategoriom każdorazowo wykracza poza obszar bezpośredniego doświadczenia moralnego i tym samym przyczynia się do re-interpretacji oraz pojęciowego określenia tego, co w sferze moralności praktykowanej jest warunkowane przez swoiste dla niej wewnętrzne prawidłowości ${ }^{46}$. Badania nad historią kształtowania się pojęciowego aparatu etyki filozoficznej umożliwiają ujawnienie w każdym z jej systemów i konkretyzacji wewnętrznego napięcia, będącego wynikiem swoistej dynamiki historii pojęć. Istotę tej dynamiki oraz „pracę” danego pojęcia ukazać ma właśnie hermeneutyka, która kształtuje element krytyczny w procesie jego użycia. Związek między procesem tworzenia pojęć a uzusem językowym jest, jak wykazuje Gadamer, niezwykle ścisły, a hermeneutyka jako historia fronetycznego rozumienia pojęć powinna „śledzić ruch myśli, który wychodzi poza zastany zwyczaj językowy i uwalnia intencje znaczeniowe słów od związku z dziedziną ich pierwotnego zastosowania" ${ }^{47}$. Historyczny horyzont rozumienia odsłania zarazem wycinkowość każdorazowego użycia pojęć, ukazując, że nie ma możliwości ich spetryfikowania w języku. W perspektywie hermeneutyki filozoficznej pojęcia nie mogą być rozumiane jako

${ }^{44}$ Por. O. Marquard, Pytanie o pytanie, na które odpowiedzia jest hermeneutyka, [w:] tegoż, Rozstanie z filozofia pierwszych zasad. Studia filozoficzne, tłum. K. Krzemieniowa, Warszawa: Oficyna Naukowa 1994, s. 120-150.

${ }^{45}$ W. Benjamin, O pojęciu historii, tłum. K. Krzemieniowa, [w:] tegoż, Anioł historii: eseje, szkice, fragmenty, tłum. K. Krzemieniowa, J. Sikorski, oprac. H. Orłowski, Wyd. Poznańskie, Poznań 1996, s. 416.

${ }^{46}$ Por. A. Anzenbacher, Wprowadzenie do etyki, tłum. J. Zychowicz, Wyd. WAM, Kraków 2008, s. 11, a także H.-M. Baumgartner, O konieczności systematycznego i historycznego uprawiania etyki filozoficznej, „Acta Universitatis Lodziensis. Folia Philosophica” 1988, nr 6, s. 49.

${ }^{47}$ H. G. Gadamer, Historia pojęć jako filozofia, tłum. K. Michalski, [w:] tegoż, Rozum, słowo, dzieje. Szkice wybrane, tłum. M. Łukasiewicz, K. Michalski, PIW, Warszawa 1979, s. 103. 
jednoznacznie określone znaki semantyczne, posiadające ściśle przypisaną funkcję. Dlatego rekonstrukcja czasowej relacji pomiędzy pojęciami a stanami rzeczy stanowi clou historii pojęć. Relacja ta, jak zauważa Reinhart Koselleck, nigdy nie jest relacją symetryczną, ponieważ zarówno pojęcia, jak i poszczególne stany rzeczy mają swoje własne dzieje, które, choć wzajemnie do siebie odsyłają, to jednak nie pokrywają się całkowicie, a ich wewnętrzne przemiany nigdy nie przebiegają synchronicznie ${ }^{48}$. Dlatego właśnie Gadamer stwierdza, że język, w tym także język pojęć, nie może być dobrowolnie modyfikowany i „przykrajany” dla partykularnych potrzeb, ponieważ „pochodzi z żywiołu, w którym poruszamy się, gdy myślimy"9.

Proces tworzenia pojęć, rozpoczynający się w świecie językowo zinterpretowanym, nie jest więc nigdy zaczynaniem od początku. Nie da się porównać z wykuwaniem od początku. Nie da się porównać $\mathrm{z}$ wykuwaniem nowego narzędzia $\mathrm{z}$ jakiegoś odpowiedniego materiału. Tworzenie pojęć jest bowiem myśleniem dalej w języku, w którym mówimy, i w zawartej w nim wykładni świata. Nie zaczyna się wówczas nigdy od zera ${ }^{50}$.

Historia pojęć, pośrednicząc między historią języka a historią przedmiotową, jest w stanie wskazać na związek abstrakcyjnej terminologii filozoficznej

${ }^{48}$ Koselleck pisze: „Wortbedeutung und Wortgebrauch verhalten sich niemals zur sogenannten Wirklichkeit in einem Verhältnis von eins zu eins. Beide, Begriffe und Wirklichkeiten, haben ihre je eigene Geschichte, die zwar aufeinander verweisen, die sich aber auf unterscheidbare Weise ändern. Vor allem ändern sich Begriffe und Realität mit unterschiedlichen Geschwindigkeiten, so daß mal die Begrifflichkeit der Wirklichkeit, mal die Wirklichkeit der Begrifflichkeit vorauseilt". R. Koselleck, Begriffsgeschichten. Studien zur Semantik und Pragmatik der politischen und sozialen Sprache, Suhrkamp, Frankfurt am Main 2006, s. 67.

${ }^{49}$ Ten element Gadamerowskiej krytyki języka przypomina rozróżnienie poczynione przez Emmanuela Levinasa między tym, co mówione (le dire) a tym, co powiedziane (le dit). Jakkolwiek filozoficzny kontekst i cel, który przyświeca francuskiemu myślicielowi jest całkowicie odmienny, to jednak on także zauważa, że " mówienie znajduje się we władzy tego, co powiedziane; że to, co powiedziane, zastyga niczym wyrocznia", pomimo iż mówienie jest „uprzednie wobec znaków, które łączy, uprzednie wobec systemów językowych i niuansów semantycznych", to mówienie zawsze „podporządkowuje się powiedzianemu, systemowi językowemu i ontologii”, gdyż ,jest to cena, jakiej wymaga ukazanie”. Dlatego w przekonaniu Levinasa „mówienie musi zdradzić siebie ukazując się w pewnym temacie”. Por. E. Levinas, Inaczej niż być lub ponad istotą, tłum. P. Mrówczyński, Wyd. Fundacja Aletheia, Warszawa 2000, s. 14-17. Szerzej na temat relacji między hermeneutyką Gadamera a etyką Levinasa por. P. Dybel, Oblicza hermeneutyki, Universitas, Kraków 2012, s. 235-244, 267-280, 287-296.

${ }^{50}$ H.-G. Gadamer, Historia pojęć jako filozofia, tłum. K. Michalski, [w:] tegoż, Rozum, słowo, dzieje. Szkice wybrane, tłum. M. Łukasiewicz, K. Michalski, PIW, Warszawa 1979, s. 93. 
z żywym językiem i tym samym, jak twierdzi Gadamer, uwolnić tę pierwszą ze „scholastycznego skostnienia” i ponownie odzyskać jej pierwotną witalność. Analizując pojawiające się w procesie historycznym konwergencje, przesunięcia i rozbieżności w relacji między pojęciem a zwyczajem językowym, historia pojęć jest w stanie odtworzyć napięcie myśli, które pojawia się z chwilą „wypaczenia” pojęcia, co sprawia, że w efekcie słowa odklejają się od świata ${ }^{51}$.

Dla etyki rozumianej jako hermeneutyka moralności postulat ten oznacza przede wszystkim konieczność podejmowania ciągle na nowo re-interpretacji własnej struktury pojęciowej i poszukiwania odpowiedzi w konfrontacji z nieustannie zmieniającymi się społecznymi warunkami epoki późnej nowoczesności. Dynamiczny rozwój biotechnologii oraz nauk medycznych odkrywa nowe obszary problemowe, z którymi etyka filozoficzna musi się jakoś uporać. Ewentualna odpowiedź, czy jej dotychczasowa struktura kategorialna, siatka pojęciowa, sposób rozumienia powinności moralnych jest dla tego celu adekwatna i może przynieść efekty, jest uzależniona od ponownego ich przemyślenia i praktycznego przepracowania, które w perspektywie hermeneutycznej sprowadza się do rozjaśnienia podmiotowej świadomości moralnej, w efekcie czego, jak mówi Gadamer, może uda się „nieco bardziej świadomym uczynić to, co wszyscy wiedzą"52. Efektu tego nie da się jednak osiągnąć bez pośredniczącej roli hermeneutyki w przełożeniu na poszczególne dyskursy. Jak podkreśla Gadamer, zrozumienie wymaga umieszczenia tego, co jest przedmiotem rozumienia na nowo w języku. Stąd hermeneutyka jest zawsze pośredniczeniem i przekładem, inter-pretacją właśnie ${ }^{53}$. W kontekście etyki filozoficznej owo pośredniczenie będzie dokonywać się pomiędzy logosem a ethosem, pomiędzy podmiotową świadomością moralnych zobowiązań a konkretną sytuacją społeczną i życiową jednostki ${ }^{54}$. Jednak już od początku myśl ta napotyka poważne trudności, które najwyraźniej uwidaczniają się w pytaniu o formę tego pośredniczenia. Zdystansowana wiedza

\footnotetext{
${ }^{51}$ Myśl ta nieobca była już Konfucjuszowi, gdy w Dialogach zalecał rozpocząć naprawę państwa od ustalenia zakresu i znaczenia pojęć.

${ }^{52}$ Por. A. Przyłębski, Etyka w świetle hermeneutyki, Oficyna Naukowa, Warszawa 2010, s. 189.

${ }_{53}$ Por. H.-G. Gadamer, Hermeneutyka klasyczna i filozoficzna, tłum. A. Mergler, [w:] tegoż, Teoria, etyka, edukacja. Eseje wybrane, wybór R. Godoń, wstęp i opracowanie P. Dybel, Wyd. UW, Warszawa 2008, s. 68.

${ }^{54}$ Por. D. J. Schmidt, Hermeneutic as Original Ethics, [w:] Hermeneutic Rationality. La rationalité herméneutique, red. M. L. Portocarrero, L. A. Umbelino, A. Wierciński, LIT Verlag, Münster 2012, s. 31-42.
} 
teoretyczna nie potrafi bowiem znaleźć przejścia do konkretności świata życia, który za pomocą sumienia, bezwarunkowego wyczucia tego, co słuszne czy chrześcijańskiego wezwania do miłości bliźniego potrafi częstokroć lepiej sprostać pojawiającym się roszczeniom moralnym. Stąd coraz częstsza chęć przekształcenia etyki filozoficznej w teorię postępowania, ujawniająca się w modzie na etykę stosowaną i kodeksową, w których dostrzega się remedium na aplikacyjne trudności etyki filozoficznej ${ }^{55}$. Nadzieja taka musi oczywiście okazać się płonna, ponieważ kodeks etyczny, mając charakter raczej „moralnej busoli” niż nakazu, nie jest wystarczającym warunkiem rozstrzygnięcia i tym samym nie usuwa dylematyczności samego wyboru moralnego. Etyka rozumiana jako filozofia praktyczna nie może być zatem prostą aplikacją teorii do sfery praktyki życiowej, lecz musi wyrastać z samej praktyki życia codziennego i być zakorzeniona w jego pierwotnej rozumności ${ }^{56}$.

\section{Bibliografia}

Anzenbacher A., Wprowadzenie do etyki, Kraków 2008.

Arystoteles, Etyka nikomachejska, [w:] tegoż, Dzieła wszystkie, Warszawa 1996.

Bacon F., Przedmowa do „Wielkiej odnowy”, [w:] tegoż, Novum Organum, Warszawa 1955.

Benjamin W., O pojęciu historii, [w:] tegoż, Anioł historii: eseje, szkice, fragmenty, Poznań 1996.

Baumgartner H.-C., O konieczności systematycznego i historycznego uprawiania etyki filozoficznej, „Acta Universitatis Lodziensis. Folia Philosophica”, 1988, nr 6.

Berti E., The Reception of Aristotle's Intellectual Virtues in Gadamer and the Hermeneutic Philosophy, [w:] The Impact of Aristotelianism on Modern Philosophy, Washington 2003.

Böhme G., Filozofia i estetyka przyrody, Warszawa 2002.

Cassirer E., Substancja i funkcja. Badania nad podstawowymi problemami krytyki poznania, Kęty 2008.

Descartes R., Reguly kierowania umysłem, [w:] tegoż, Reguły kierowania umysłem. Poszukiwanie prawdy poprzez światło naturalne, Kęty 2002.

Dybel P., Oblicza hermeneutyki, Kraków 2012.

\footnotetext{
${ }^{55}$ Por. H. Krämer, Etyka integralna, tłum. M. Poręba, Wyd. Rolewski, Nowa Wieś k/Torunia 2004, s. 261.

${ }^{56}$ Por. H.-G. Gadamer, Obywatele dwóch światów, [w:] tegoż, Dziedzictwo Europy, tłum. i oprac. A. Przyłębski, Wyd. Spacja, Warszawa 1992, s. 75.
} 
Figal G., Ethik und Hermeneutik, [w:] H.-M. Schönherr-Mann, Ethik als Hermeneutik, München 2004.

Gadamer H.-G., O możliwościach etyki filozoficznej, [w:] tegoż, Teoria, etyka, edukacja. Eseje wybrane, Warszawa 2008.

Gadamer H.-G., Ethos und Ethik, [w:] tegoż, Gesammelte Werke, Bd. 3: Neuere Philosophie I. Hegel, Husserl, Heidegger, Tübingen.

Gadamer H.-G., Hermeneutik als praktische Philosophie, [w:] Rehabilitierung der praktischen Philosophie, Verlag 1972.

Gadamer H.-G., Hermeneutyka klasyczna i filozoficzna, [w:] tegoż, Teoria, etyka, edukacja. Eseje wybrane, Warszawa 2008.

Gadamer H.-G., Historia pojęć jako filozofia, [w:] tegoż, Rozum, słowo, dzieje. Szkice wybrane, Warszawa 1979.

Gadamer H.-G., Idea dobra w dyskusji między Platonem a Arystotelesem, Kęty 2002.

Gadamer H.-G., Obywatele dwóch światów, [w:] tegoż, Dziedzictwo Europy, Warszawa 1992.

Gadamer H.-G., Teoria, technika, praktyka, [w:] tegoż, Teoria, etyka, edukacja. Eseje wybrane, Warszawa 2008.

Gadamer H.-G., Vernunft und praktische Philosophie, [w:] tegoż, Gesammelte Werke, Tübingen 1995, t. 10.

Gadamer H.-G., Wertethik und praktische Philosophie, [w:] tegoż, Gesammelte Werke, Bd. IV: Neuere Philosophie II. Probleme - Gestalten, Tubingen 1987.

Hommes U., Kanta krytyka praktycznego rozumu a współczesna filozofia praktyczna, „Studia Filozoficzne”, 1973, nr 4.

Koselleck R., Begriffsgesichten. Studien zur Semantik und Pragmatik der politischen und sozielen Sprache, Frankfurt 2006.

Krasnodębski Z., Rozumienie ludzkiego zachowania. Rozważania o filozoficznych podstawach nauk humanistycznych i społecznych, Warszawa 1986.

Levinas E., Inaczej niż być lub ponad istota, Warszawa 2000.

Łepko Z., Spór o testament F. Bacona, „Studia Philosophiae Christianae” 1998.

Narecki K., Słownik terminów Arystotelesowych, [w:] Arystoteles, Dzieła wszystkie, t. 7, Warszawa 1994.

Nowak-Juchacz E., Autonomia jako zasada etyczności. Kant, Fichte, Hegel, Wrocław 2002.

Przyłębski A., Etyka w świetle hermeneutyki, Warszawa 2010.

Przyłębski A., Gadamer, Warszawa 2006.

Przyłębski A., Hermeneutyczny zwrot filozofii, Poznań 2005.

Ricoeur P., Hermeneutyka symboli a refleksja filozoficzna, [w:] tegoż, Egzystencja i hermeneutyka. Rozprawy o metodzie, Warszawa 1985.

Schnädelbach H., Hegel. Wprowadzenie, Warszawa 2006.

Siwiec T., Etyka filozoficzna jako normatywna refleksja krytyczna, „Kultura i Wartości” 2012, nr 1, (www.kulturaiwartosci.umcs.lublin.pl/wp-content/uploads/2011/11/ 
Tomasz-Siwiec-Etyka-filozoficzna-jako-normatywna-refleksja-krytyczna2.pdf (dostęp: 27 maja 2013 r.)).

Spaemann R., Die Aktualität des Naturrechts, [w:] tegoż, Philosophische Essays, Stuttgart 1994.

Spaemann R., Löw R., Cele naturalne. Dzieje i ponowne odkrycie myślenia teleologicznego, Warszawa 2008.

Szulakiewicz M., Filozofia jako hermeneutyka, Toruń 2008.

Vattimo G., Poza interpretacją. Znaczenie hermeneutyki dla filozofii, Kraków 2011.

Vattimo G., Społeczeństwo przejrzyste, Wrocław 2006.

Vattimo G., Społeczeństwo przejrzyste, Wrocław 2006.

Wright G. H., Explanation and Understanding, London 1971.

\section{Abstract \\ Philosophical ethics as hermeneutics of morality}

Author contemplates the relations between hermeneutics and philosophical ethics. He conceives ethics as normative and critical reflections on one hand, and as hermeneutics of morality on the other. Similarly to Gadamer author points out the meaning of phronesis and calls for return to the idea of practical philosophy, which is able to grasp all of the life world and which is articulated in laws and customs. Basis for that meaning of philosophical ethics consist in ethos. Self-presentation of that ethos take place in social form of life. Philosophical ethics conceived as hermeneutics of morality, rise in mere practice of everyday life and roots in its primal rationality.

Key words: Philosophical ethics, hermeneutics, hermeneutics of morality, ethos, practical philosophy, H.-G. Gadamer 